\title{
The Concept of Grotesque in Harry Potter
}

\author{
Ashti Anwar Muhammad, Asma Jasim Muhammad \\ Department of English, School of Languages, University of Sulaiamani, Sulaiamani, Iraq \\ Email address: \\ ashti.anwar@yahoo.com, (A. A. Muhammad), asma.muhammad11@yahoo.com (A. J. Muhammad)
}

\section{To cite this article:}

Ashti Anwar Muhammad, Asma Jasim Muhammad. The Concept of Grotesque in Harry Potter. International Journal of Literature and Arts. Vol. 3, No. 5, 2015, pp. 98-102. doi: 10.11648/j.ijla.20150305.15

\begin{abstract}
Over the last years, the Harry Potter series by J. K. Rowling has become popular, becoming one of the most read and most criticized pieces of literature to date. As a result of its adult success, Harry Potter has drawn the attention of several writers to follow serious literary analyses, most frequently exploring many didactic themes such as reality, evil and religion. However, the focus of this research is to pinpoint the idea of grotesque in Harry Potter series. This concept is on scary and unusual creatures, between being funny and frightening. It is a sort of fusion of humans with animals. Those creatures add colorful aspects of creative literary writing within the fictional "wizarding world" contained in the Harry Potter. Throughout the seven books of the series, Harry and his friends come across man these creatures on their adventures. Many of these are derived from folklore, primarily Greek mythology, but also British and Scandinavian folklore. Many of the legends surrounding mythical creatures are also incorporated in the books.
\end{abstract}

Keywords: Harry Potter, Grotesque, Funny and Children

\section{Introduction}

The word Grotesque is derived from Italian grotte, 'caves.' Crotesque was used for the first time in French 1532 and this form was also used in English until it was replaced 1640 by Grotesque. Grotesque denotes a kind of decorative ornament consisting of medallions, sphinxes, foliage, rocks and pebbles. Because they were found in grottoes they were called grotteschi. The term came to be applied to paintings which depicted the intermingling of human, animal and vegetable themes and forms (Cuddon 367).

The extension of the word to a literary context may well have occurred in $16^{\text {th }} \mathrm{c}$. France. Rabelais, for example, uses it as concerning parts of the body. But it does not seem to have been used regularly in a literary context until the $18^{\text {th }} \mathrm{c}$., the period of the age of reason and Neoclassicism, when it was commonly employed to denote the ridiculous, bizarre, extravagant, freakish and unnatural; in short, aberrations from the desirable norms of harmony, balance and proportion (Cuddon 367). The writer employs grotesque for comic and satirical purposes. In literature one is most likely to find grotesque elements in caricature, parody, satire, invective, burlesque, black comedy, the macabre and what is known as the Theatre of the Absurd. Grotesque is often a constituent of comical relief, the sick joke, sick verse and pornography. Excellent examples of the grotesque can be found in the works by Rabelais, Skelton, Webster and Samuel Beckett (Cuddon 368).

Obviously, this architectural term has other meanings when it comes to literature, it can be defined as "the natural into absurdity, ugliness, or caricature." It is also synonymous with monster, bizarre, unexpected, atypical, and unnatural. In literary fiction, the grotesque has evolved over the years, originating in stories and fables, and in mythology. What a great place to create these monsters, these aberrations, these fascinating beasts, gods, and mortals. When we read about grotesque, we are reminded of the Cyclops, Medusa, the hydra, and of course - the kraken. We wonder how many people watched Clash of the Titans. We think the same applies for other more contemporary beasts and urban legends: the chupacabra, the werewolf, and the yeti, for example. There's a reason that vampires and zombies are so captivating, why we are interested in a character like Gollum. The carnivals of the 1920s and 1930s are another atmosphere where the grotesque was commonplace: the sideshow freaks such as the bearded woman, the elephant man, Siamese twins, and the lion-faced boy. Some of the earliest written texts describe grotesque happenings and monstrous creatures. The literature of Myth has been a rich source of monsters; from the one-eyed Cyclops, from Hesiod's Theogony to Homer's Polyphemus in the 
Odyssey. Ovid's Metamorphoses is another rich source for grotesque transformations and hybrid creatures of myth.

One can see Gollum as a failing mortal, he has made his choices, and while he is certainly disgusting, a horribly disfigured creature, he was once innocent. And he still has feelings, still desires the ring, his obsession and his precious. We have compassion for these outsiders, whether they are Edward Scissorhands, or Flannery O'Connor's Misfit, or the variety of strange creatures in Alice in Wonderland. It's a built-in conflict, the Beast from Beauty and the Beast, the desire for the monster to change, to evolve, to become more human, more forgiving, to find love. One finds this a lot in fairy tales and fables. People root for the abomination, renounce the inherent evil within, and change.

When reading an article by Flannery O'Connor on the grotesque, we realize for the first time that this term doesn't just refer to people, it can also be an event. Written in 1960, her essay titled "Some Aspects of the Grotesque in Southern Fiction." In it she demonstrates a brilliant perspective on stories based on grotesque. She claims that grotesque blows into the mixture of dreadful and idealistic. Also, it takes those trappings and moves them to a specific place and time. These stories which are based on grotesque examine the values of the characters, while showcasing flawed, disturbing, and lost characters, as well as decayed and derelict settings. Within that window of focus we often find the grotesque.

In reading grotesque works like Bram Stoker's Dracula, J.K.Rowling's Harry Potter or Tolkien's 'The Lord of the Rings', we find out that the writer of grotesque has made some experiences alive, which we are not accustomed to observe every day, or which the ordinary man may never experience in his ordinary life. We find that connections which we would expect in the customary kind of realism have been ignored, that there are strange skips and gaps which anyone trying to describe manners and customs would certainly not have left out. Yet the characters have an inner coherence, if not always a coherence to their social framework. Their fictional qualities lean away from typical social patterns. In order to have a close eye on the concept of grotesque, we would have to read the celebrated series of Harry Potter.

Harry Potter is a series of seven fantasy novels written by British author Joanne Kathleen Rowling, 1965. Joanne grew up surrounded by books as her parents loved reading and from an early age Joanne wanted to be a writer. But her life was not an easy one. She was very poor and struggling to earn money for her family. This explains the success story of one woman who never gave up during her worse-case scenario. In 1990 Rowling was determined to write a book using these words about an orphaned boy, who is mistreated by his aunt and uncle and finds himself being a Wizard. J.K. Rowling first had the idea for Harry Potter while delayed on a train travelling from Manchester to London in 1990. Over the next five years, she began to plan out the seven books of the series. Each novel corresponds to a year, long period of time, usually in reference to Harry Potter's year at Hogwarts School of Witchcraft and Wizardry. The series chronicles the adventures of a young wizard, Harry Potter. Harry Potter is an orphan who lives with his mean aunt, uncle and cousin. He gets asked to attend Hogwarts School of Witchcraft and Wizardry because he is a wizard. He finds out that he is famous because he is the only person ever to have survived the killing curse. He makes two friends, Ron Weasly, and Hermione Granger. In his first year, he defeats Lord Voldemort, the wizard who tried to kill him. In the second, he stabs and kills the monster of the Chamber of Secrets, a large basilisk. In his third year, he seeks revenge on Sirius Black, the man whom he thought had betrayed his family to Voldemort. He later learns that Sirius is his godfather, and an innocent man. In his fourth year, Harry is forced by an evil wizard disguised as an auror (a dark wizard catcher) to be part of the triwizard tournament. He and Cedric Diggory win together, and Cedric is killed after ward by Voldemort's servant. Harry then witnesses the return of the dark wizard who tried to kill him. In the fifth movie, Harry is disliked by the Ministry of Magic, who are trying to run Hogwarts by hiring an evil teacher, Delores Umbridge. His godfather, Sirius is later killed, and he discovers a prophecy which states that "Neither one can live while the other survives." In the sixth year, the hogwarts headmaster, Albus Dumbledore, is killed by a teacher, Severus Snape. In the seventh and final year, Harry, Ron and Hermione find and destroy all of the hocuses that Voldemort has been using to return to life after dying. Harry and Voldemort then face off, and Harry kills Voldemort.

\section{The Ancient Use of Grotesque and J. K. Rowling's Grotesque}

From the earliest times, people fulfilled their need to explain their world and to realize their questions by creating myths about all kinds of phenomena. They were taking comfort and instruction from the idea of supernatural beings dominating and controlling the wonders of human existence. The old term of grotesque is often linked with satire and tragicomedy. It is an effective artistic means to convey grief and pain. Ancient grotesque has always evoked big interest because they deal with wide range of questions, almost universal. It existed as an artistic mode as far back as the early Christian period of Roman culture, where there evolved a style of combining human, animal and vegetable elements, intricately interwoven, in one painting.

Grotesque characters are legendary creatures that are believed to be real beings, but some have their origin traced from literary myths. Those creatures can be divided into two groups: The first group consists of creatures whose existence everybody agrees on or still exists today. The other group consists of creatures whose existence not everybody believes in. While the first group refers to the literary works and oral transmission, its impact becomes stronger during the course of time. The story changes into legend and the legend becomes history. The second group consists of more unreliable sources such as fairy tales. Of course people have been interested in them, if they are real or not. These creatures are depicted in more aggressive way.

Grotesque in books of J. K. Rowling is noticeable at first 
sight. There are many creatures which people know from fairy tales. Moreover, those who are more familiar with mythology find that the name of each character and even of every creature is all chosen from mythology. We understand that Rowling at first chose the mythological characters and created Harry Potter's characters after mythological ones. Why did she do that? And what are the basic structures of mythology in the books of Harry Potter? The reason might be to emphasize the battle between the good and the evil. The whole story is based on this topic. The good and the evil are obvious in the two main characters. Harry is supposed to be the good one, and Voldemort the bad one.

Grotesque characters are the key to people's identity. Names also have the function of differentiation. It means that we can recognize people by their names. Some names have the ability to express character traits or personal appearance but they can also insinuate places, professions or accidental circumstances, which were connected with the particular individuals. Later many of these descriptive names became surnames, for example:

Argus, in Harry Potter, Argus Filch was a caretaker of Hogwarts School of Witchcraft and Wizardry. He usually wandered around the school corridors, trying to catch students breaking the school rules. He owned a cat named Mrs. Norris. In ancient mythology, Argos was a monster that had a hundred eyes and could see everything. Argos was also the guard. Filch in Harry Potter wanted to have hundred eyes to see everything and wanted to be everywhere. Here is the connection with mythological Argus.

Also, Basilisk in Harry Potter, Basilisk is a giant serpent, also known as the King of Serpents. It can grow up into the giant size and live for many centuries. It has deadly poisoned teeth and stares. Anybody who looks in its eyes will die immediately on the spot. Whilst, the ancient Greek meaning for basilisks is "little king" or "little tyrant," a huge bird with a serpent's tail could kill with its stare and also breathe fire. Basilisk is also called the king of all serpents. J. K. Rowling directly followed the mythological track. There are almost no differences between her books and the ancient mythological facts about the basilisk. The only thing which she made up is that the basilisk was moving through the pipelines. This fact isn't mentioned in Mythology. Of course it couldn't be, because in those days there were no pipelines, so J. K. Rowling had to come up with this idea at first.

Giants and Trolls are depicted in Harry Potter as huge monsters, really strong ones, but very stupid. Giants are evill. In ancient Mythology, the word giant comes from the Greek Gigantes (meaning earthborn). Giants were half monsters, half men. Giants are often cruel and evil, although they may also be simply clumsy or stupid. In some myths and legends, however, they are friendly and helpful or at least neutral. In this case J. K. Rowling didn't come up with any new idea. Giants in Harry Potter are completely same as in Mythology. They are big but stupid. They are evils but when they appear in some stories or legend or in this case in the book of Harry Potter, they are good and neutral to people (Kubatova 35-37).

\section{Description of Grotesque in Harry Potter}

J.K. Rowling included her series within grotesque. She intended to do that on purpose to show how it is great to create tension and disgust in horror at the same time; how to build worlds in fantasy; how to interact with technology when writing science fiction; how to slowly reveal the conflict and answers in mysteries and crime and how to tap into emotional truths when writing about this topic.

Those creatures that Rowling took from myth and folklore are for example (Beasts, Spirits, status unknown, Boggarts, Centaurs, Giants, Goblins, Thestrals and Doddy). In one of her interviews on BBC Radio. 13 November 2009, she axclaimed : "people. .. know that I didn't invent unicorns, but I've had to explain frequently that I didn't actually invent hippogriffs. When I do use a creature that I know is a mythological entity, I like to find out as much as I can about it. I might not use it, but to make it as consistent as I feel is good for my plot."

Although inspired by folklore and old myths, Rowling does not depend on supernatural. Rather, there is a dark humor in the stories. It follows the idea of exposing the problems of society, but does so by developing complex and strange characters. She explores the behaviors of people (usually strange) and the social order of the society. Through the series of Harry Potter, the author hoped to show that the social order was fragile and the realities behind it were actually disturbing. She works to point out truths and the problems of culture and its moral shortcomings. The themes that these series show are developed around these goals.

The grotesque characters are usually complex, and many of them are mentally unstable. Many of the characters are broken in spirit and struggling to find a place in society once again. The morality of those characters is often questioned. Through those characters, Rowling examines the harm that people can do to each other. Also, she pictured many characters that are seen as innocent, such as the mentally handicapped, and there is a struggle for their place in the world. Whether mentally unstable, dark, or innocent, the characters try to make sense of the world around them and the society in which they live.

Rowling honestly added grotesque in her series because she looks at the grotesque in three ways: as a reflection of the real world, as an artistic mode and as the product of a certain kind of temperament. The latter consideration involves, of course, psychological analysis and speculation, an approach which brings obvious dangers with it as one must rely on getting at the grotesque through the mental make-up and artistic temperament of the author. J. K. Rowling didn't just write some fairy tale about a wizardly boy. She hid some message there too.

\section{J. K. Rowling's Use of Grotesque in Harry Potter}

Grotesque characters that J. K. Rowling set are holders of social message. Through them, she endeavored to tell us that 
behind their maybe ugly or strange outlook differences which divide each culture of the world, could be, some common foundation. In human mind there is something inexplicable which attracts people so much. They react equally all around the world to the plots and dramas. They react with amazement. Those characters talk with the universal language. They show us that cultures penetrate from one to another and the base is unity of humanity.

Rowling's magical world serves quite a different purpose, indicated by the fact that Harry leaves the normal world to enter the magical world, where he remains. We discover that a magical world has long stood beside our own, in secret. Harry learns he is a wizard when Hagrid announces this fact and presents his invitation to the Hogwarts School of Witchcraft and Wizardry. At the end of the series, after Harry's allies defeat, Voldemort, Harry and his friends continue to live in the magical world; the magic remains as strong as ever. While Rowling creates a fictional divide between the magical world and the Muggle (mudblood) world, what is significant about her novels is that the heroes live in the magical world, embrace it, fight for it, and remain in it always and this world is full of grotesque characters.

Rowling's Harry Potter, is cast in terms of a good side, and a bad side beauty against ruthless ugliness, tyranny against kingship, moderated freedom with consent against compulsion that has long lost any object save mere power, and so on; but both sides in some degree, conservative or destructive, want a measure of control. Rowling has an unusual ability to weave stories together, controlling her complex plots with considerable verve. But a story is not good only because of its drama; Rowling is sound in the emotional underpinning of her tales and funny in the telling of them, both of which play a part in absorbing the attention of her readers so completely.

Rowling is very ambitious and has accomplished every detail in the plot of the series. She is able to create tensions and chilling effects such as the terrors of the Dementors even within the security of the predictable. Rowling, even as a novice writer with a tendency towards a naïve turns of phrase, is a strong storyteller. She tells a simple story deftly, controlling the pace with enough twists and turns to keep readers waiting and guessing. She is able to imply attitudes through well-judged humor rather than preaching (Ecceshare $35)$.

J. K. Rowling added the concept of grotesque to confirm various kinds of powers, scary and reassuring; funny and full of pathos. It is to show her ability to write at a greater depth and to scare. It offers rollicking adventure from a setting that is both entirely safe and inventive enough to captivate and entertain. But the story on its own would not be remarkable, although Rowling's control over the plot is impressive. It is strengthened by the underlying messages about racism and tolerance, education and family values that are lightly but securely woven into the fabric of the story. Those creatures that she add is to enrich her novels with scare, magic and secrets, Rowling is very challenging and interesting and she is able to carry her readers with her.

\section{Conclusion}

Rowling's work became wildly popular in the United Kingdom, and when released by Scholastic in the United States a year later, it became an international phenomenon. Through these books, children and young adults alike, have delved into a fantastical world in which they explored the problems that their protagonist, Harry Potter, has faced. In Harry Potter, J.K. Rowling uses points of view, style, and irony to demonstrate the need for people to be more analytical towards sources of authority. Through Harry Potter's interactions with other freak creatures, Rowling shows how a lack of criticism towards one's sources of influence can lead to undesirable consequences. In doing so, Rowling demonstrates how we [people] give into basic instincts. Strictly speaking, Rowling is a captivating storyteller and her skill lies not just in the drama of the obvious narrative but in the meticulous detail of the plots. So, the result is that, although the substance of the story is sinister, there is lightness about Rowling's writing that shows just how inventive she can be. As ever, she keeps her invention close to an original, Rowling that shines.

Rowling pours invention that is impressive in its intense visual appeal. The aim of this work is to explain the concept of grotesque in Harry Potter. We honestly have to say that we tried to fulfill our task. We discovered many effects here. After studying of J. K. Rowling's Harry Potter we came to a conclusion that she mostly used characters and beasts from Greek Mythology. She created her characters on the basis of mythology such as, The Iliad, The Bible, The Pardoner's Tale and gave them some extra personalities. She mostly tried to soften their behaviour. We also discovered some other mythological features in Rowling's series (as mythical hero, mythical child and the fight against evil and good).

Furthermore, she might have drawn upon numerous mythological sources to create it but she did indeed create something unique, something that hadn't been touched before. The credit for uniting the different legends and myths and creating a new world out of them goes entirely to her. We found that J. K. Rowling wrote her books in a very clever way and attracted the attention of its readers.

\section{References}

[1] Anatol, Giselle Liza. Reading Harry Potter: Critical Essays. No. 78. Green Wood Publishing Group, 2003.

[2] Berman, Lauren. "Dragons and serpents in JK Rowling's Harry Potter Series: are they evil?" Mythlore 27.1-2 (2008): 45.

[3] Cummins, June. "Hermione in the bathroom: The Gothic, menarche, and female development in the Harry Potter series." The Gothic in children's literature: Haunting the borders (2008): 177-193.

[4] Gunelius, Susan. Harry Potter: The story of a global business phenomenon. Palgrave Macmillan, 2008.

[5] Heilman, Elizabeth E., ed. Critical perspectives on Harry Potter. Routledge, 2008. 
[6] Mills, Alice. "Harry Potter and the Horrors of the Oresteia." Critical Perspectives (2008): 243-256.

[7] Natov, Roni. "Harry Potter and the Extraordinariness of the Ordinary." The Lion and the Unicorn 25.2 (2001): 310-327.

[8] Nel, Philip. J. K. Rowling's Harry Potter Novels: A Reader's Guide. A\&C Black, 2001.
[9] Robertson, Judith P. "What happens to our wishes: Magical thinking in Harry Potter." Children's Literature Association Quarterly 26.4 (2001): 198-211.

[10] Russo, Mary J. The Female Grotesque: Risk, Excess, and Modernity. Psychology Press, 1995.

[11] Strimel, Courtney B. "The politics of terror: rereading Harry Potter." Children's Literature in Education 35.1 (2004): 35-52. 